PRZEGLĄD BIBLIOTECZNY 2019

e-ISSN 2545-2487

KATARZYNA ŽÁK-CAPLOT

Library of Museum of Warsaw

e-mail: katarzyna.zak@muzeumwarszawy.pl

ORCID: 0000-0002-4114-8082

\title{
AN UNEXPLORED PHENOMENON ON THE BORDER OF TWO WORLDS. AN INTRODUCTION TO THE ISSUE OF MUSEUM LIBRARIES IN POLAND
}

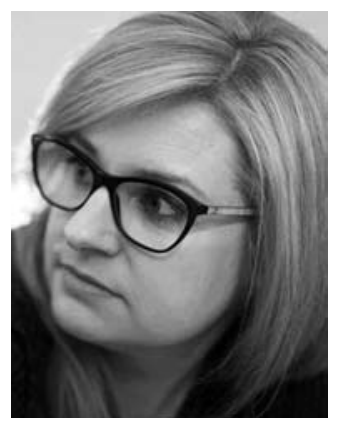

KATARZYNA ŽÁK-CAPLOT, M.A., long-time employee of the Acquisition Department and the Library and Documentation Education Department of the National Library of Poland, currently manages the library network of the Museum of Warsaw. Her scientific interests include the phenomenon of museum libraries in Poland and around the world, and the integration of elements of library and museum education as part of language teaching using the subject-language method. Holder of a scholarship from the Kościuszko Foundation in America and winner of the European Language Label 2019 for the project „Warsaw for the intermediate level student".

KEYWORDS: Museum library. Specialist library. Professional library. Museum. Statistics. Library functions

ABSTRACT: Objective - The article discusses the main concepts and sources of information about museum libraries in Poland, moving towards their definition and place in the native library system. It is an opportunity to reflect on how museum libraries operate on the border of the "museum" and "library" worlds. Method - the subject literature, surveys and statistical reports of the Central Statistical Office (Główny Urząd Statystyczny - GUS) and the National Institute for Museums and Public Collections (Narodowy Instytut Muzealnictwa i Ochrony Zbiorów - NIMOZ) were reviewed, as well as the organizational regulations of selected museums and websites of some museum libraries in Poland. The Act on Libraries of June 27, 1997 was analysed with regard to the division of national libraries 
into types. The material was analysed to try to place museum libraries within the context of the abovementioned division. Conclusions - It is difficult to study a museum library whilst applying only the set of concepts known to librarians. There is also a lack of relevant statistical data. Due to the fact that museum libraries are rooted primarily in the institution of the museum and have therefore an obligation to achieve its goals and mission, as well as to trends in the development of Polish museology, 21st century museum libraries have gone beyond the scope of professional libraries within the meaning of the Act on Libraries of June 27, 1997.

\section{INTRODUCTION:}

This article does not aspire to discuss the overall issue of changes occurring in "museum librarianship", and the conclusions formulated in it come mainly from source analysis, experience, and observation, as well as cooperation and exchange of experience with museum libraries in Poland and abroad. The author hopes that this article will help outline research fields and gaps that researchers interested in this topic will address. Driven by her own practical experience, the author will at times allow herself to highlight problems the resolution of which would be extremely useful for the entire museum librarian community in Poland.

\section{SUBJECT LITERATURE OVERVIEW:}

It is difficult to find a monograph or comprehensive scientific article on the above issue. While there is a lot of talk about libraries, museums, and archives as types of cultural institutions with similar tasks and problems, when it comes to the museum library and the principles on which it operates as well as the tasks it faces, the literature on the subject is practically silent both from the point of view of museology and library science. This part of the article presents an overview of publications published mainly in the last decade regarding the phenomenon of the museum library.

The author will briefly present the most important texts that attempt to describe the functioning of this type of unit on the border of two realities - library and museum - as well as the problems and challenges facing them and directions of their development in Poland. Moreover, she will not ignore selected texts in Polish which discuss foreign museum libraries in this respect, and foreign language monographs that are still relevant.

The most commonly found are articles describing library collections found in museums or accounts of individual libraries (Jeznak, 2009; Niechcaj-Nowicka, 2014; Siuciak, 2013; Žák-Caplot, 2018). However, these publications will be omitted here due to the lack of relevance to the topic.

The important publications from the point of view of museum libraries in Poland and attempts to define them are those that relate to their cur- 
rent activities and are written by employees of museum libraries. They describe contemporary fields of library activity, their needs, sometimes even their plans for the future. They show what challenges they face on a daily basis, without comprehensive sanctioned organizational and legal solutions. Among the latter, three publications cannot be omitted. The first is the article Coś starego, coś nowego... Analiza procesu digitalizacji zbiorów bibliotek muzealnych (Something old, something new ... Analysis of the process of digitizing museum library collections), in which Izabela Oleaszewska-Porzycka focuses on the prospects of protecting historical collections through digitization. The relation between the museum library and the museum itself is explored in the context of the policy of acquisitions and the nature of the collections themselves, and their relationship with the type of museum in which they operate. Data was collected through surveys, to which 85 institutions responded in 2012. Based on these, we can also find out the number of employees or the state of automation of the museum libraries surveyed at that time. On the margins of these investigations, the author emphasizes the uniqueness of the museum library as a cultural institution.

The second text, by Marta Kurzyńska, Biblioteka Muzeum Narodowego w Szczecinie - przemiany i perspektywy rozwoju (Library of the National Museum in Szczecin - changes and development perspectives) (Kurzyńska, 2017), describes not only this library's history, book collection, and bibliography, but also the organization and operation of the library itself. It also signals future development prospects.

The third publication, Gościnność przestrzeni. Rozmowa z Magdalena Mazik, kierowniczka biblioteki MOCAK-u (Hospitality of Space. Conversation with Magdalena Mazik, head of the MOCAK library) (Mazik, 2013), is an interview. Magdalena Mazik talks about the interplay of the old book collection and decor with the new, modern one, presents the educational and exhibition activities of the institution in a way that differs from the others because it is not of a scientific nature. The author, a cultural anthropologist by education, draws a picture of the museum library as an open and friendly place of reflection on art. She discusses the case of the library, which from the very moment of its creation was and is a modern unit in a modern cultural institution.

Publications discussing the changes taking place in specific museum libraries that have been in existence for many years are also beginning to appear. The texts presented below deal with current topics and relate to the place and condition of museum libraries in their home institutions. This is an important sign that museum libraries are no longer perceived as satellites of their parent institutions, and are beginning to be perceived as part of the whole, which is the museum. Justyna Długosz in the presentation of the Biblioteka Muzeum Ślaskiego w Katowicach - wspótczesna biblioteka 
muzealna $w$ nowoczesnej instytucji kultury (Library of the Silesian Museum in Katowice - a contemporary museum library in a modern cultural institution) (Długosz, 2018) focuses on the presentation of a modern library that, while building its own brand and identity, is at the same time a showcase of its museum.

Meanwhile, Katarzyna Žák-Caplot, in the article Biblioteka Muzealna OdNowa, czyli między drugim a trzecim miejscem (The Museum Library 'OdNowa', or: between the second and third places) (Žák-Caplot, 2018) talks about the changes that took place in the Warsaw Museum Library in 20132018 under the influence of revitalization and reorganization of the parent museum, and at the same time wonders what a museum library is in the second decade of the 21st century.

This is a very narrow group of publications, which, according to the author, will likely grow, if only due to conferences for museum librarians in Warsaw and Katowice taking place this year which are devoted to, among other things, the themes of changes in museum libraries and their future, as well as the growing need for discussion within the museum librarians' environment itself.

The last group are reports on foreign study visits published in trade magazines. Here we should mention Sławomir Sobczyk's Biblioteki muzeów sztuki na przykładzie biblioteki Arxiu CCCB w Barcelonie i Biblioteka de Arte Muzeum Gulbenkiana w Lizbonie (The library of art museums on the example of the Arxiu CCCB library in Barcelona and the Library de Arte of the Gulbenkian Museum in Lisbon (Sobczyk, 2012), and Anna Adamek's Biblioteka Muzealna - z doświadczeń muzeum narodowego nauki i techniki w Ottawie (The Museum Library - from the experience of the National Museum of Science and Technology in Ottawa) (Adamek, 2000). In the first publication, the author focuses on the activities, tasks, organisation, technological advancement and services offered by the abovementioned libraries. However, he does not attempt to define the institution of the museum library or refer to its condition in the home museum. This subject is touched upon by the author of the second article, while trying to describe in a few sentences the place of the library in the structure of the museum and the principles of cooperation between librarians and museum professionals in the selection of library collections. However, neither of these articles relates to the situation in our country.

The authors of the above publications are library studies professionals and librarians. However, the museum library operates at the juncture between the library and the museum. Therefore, texts by museum experts or institutions associated with museum studies in Poland have not been omitted. These usually arise from descriptions of Polish and foreign museums and their collections, and present information about the existence of a library with a valuable book collection. These are numerous, but they 
do not relate to the issues raised here. News about the museum library as a component of the larger unit, which is the museum itself, is brief information that must be gleaned from the text. It is usually a clarification of some other information, most often concerning investment or logistics in a specific museum or inventory and digitisation of museum exhibits in general.

One of the few texts in which the author describes the state of Polish museology in legal, economic and substantive terms is the publication of Dorota Folga-Januszewska, Muzea w Polsce 1989-2008 (Museums in Poland 1989-2008). One can find here information about museum libraries in relation to the digitisation of collections and to admission fees and services provided by museums (Folga-Januszewska, 2009).

Most often, information on museum libraries is found in articles about the construction or revitalization of museum buildings (e.g. Muzeum OdNowa ..., 2018, pp. 168-179; Makała, 2009, p. 156). Libraries are often mentioned next to educational rooms, guest rooms, cinemas or cafes as one of the ways to attract a wider audience. These types of texts, although seemingly insignificant for the subject matter, signals a gradual investment in museum libraries during the modernization or construction of new museum objects and reveals the direction of changes in new and renovated museum libraries (expanding the offer for new types of users, addressing the need for changes in the method of inventory collection or the requirement to regularly increase the number of visits to the library). For example, as part of the project to revitalize the infrastructure of the Art Museum in Łódź "[...], a modern reading room will be created on the fifth floor, in which computer workstations with access to the electronic card catalogue will be created. The library's activities will be extended to include meetings and lectures promoting readership open to the public" (Rewitalizacja infrastruktury..., 2016, p. 1). The shape and functions of the future library were decided here at the design documentation stage.

Moving on to foreign-language publications, one cannot ignore the slightly older, but still valid monographs of Esther Green Bierbaum: Museum Librarianship (Bierbaum, 2000) and Art Museum Libraries and Librarianship (Benedetti, ed., 2007). These publications are a kind of textbook for librarians and museum library employees. They define a museum library, discuss all aspects of its activity and emphasise its integrity with the home museum. At the same time, they indicate areas that librarians and managers of American museums should pay close attention to. The development of such a guide for employees of museum libraries in Poland would be desirable because questions about the status of library collections in the museum, methods of electronic inventory, book loss, keys to the selection of library system and many other issues are frequently asked. It also happens often that the "keepers of museum collections" are not librarians, but museum staff who then need a textbook. 


\section{MUSEUM LIBRARY STATISTICS}

A useful tool to explore almost any topic is statistics and analysis of the data obtained. Examination using regularities that occur in certain communities allows us to determine the state of affairs and directions in which the observed environments are evolving. Unfortunately, the data on museum libraries that we are able to obtain from research officially carried out in our country is scarce. In order to obtain such data, one should use surveys sent directly to museums or rely on interviews with their employees. GUS reports do not include issues related to museum libraries. Although most museum libraries fill out the GUS statistical form Report from the $\mathrm{K}-03 \mathrm{li}$ brary, the data obtained from this survey are not visible in the Report on the condition of libraries in Poland... Selected data and indicators.

In Poland, unlike in other countries such as the Czech Republic or Serbia, museum libraries do not constitute a separate type of library as defined in the Ustawa $z$ dnia 27 czerwca 1997 o bibliotekach (Ustawa, 1997). We usually include them in professional or scientific libraries. The only library noted in the study is the Library of the National Museum in Warsaw ${ }^{1}$, however, data related to it are assigned to scientific libraries.

As part of the project of the National Institute for Museums and Public Collections, Museum statistics, conducted since 2003, there is a research questionnaire containing questions about topics of interest to us. Apart from questions regarding museum libraries and library collections in sections IV: Scientific activity, V: Educational activity, VI: Collections and records, and XV: Financial data, in section XIII: Infrastructure we ask the key question (No. 6): Does the museum have a library? In section XVIII, discussing the socio-economic impact of museums, we raise the issue of interlibrary cooperation ${ }^{2}$. Here, however, it should be noted that a museum's collaboration with libraries does not necessarily mean that it has a working library ${ }^{3}$.

The situation is different at the level of the Museums in Poland report. Report based on data from the "Museum statistics" project. This study for 20132015 lacks information about museum libraries (Muzea w Polsce..., 2016, p. 50 $)^{4}$. In subsequent NIMOZ reports, the issue of museum libraries is also ignored or marginalized. In the publication for 2016, the word "library" appears twice - the first in the author's biography, and the second in the name of the organizer of one of the museums. However, for 2017,

\footnotetext{
${ }^{1}$ Form K-03, Department 1, Item 1, library symbol - 63 .

${ }^{2}$ In the 2018 questionnaire, letter $\mathrm{C}$ point 2

${ }^{3}$ Cooperation can take on various forms: from borrowing collections for temporary exhibitions, through joint organization of events or conferences, volunteering, etc.

${ }^{4}$ In the chapter Collection records and digitisation, there is only a mention of the incorrect extension of the library auditing principles to museum collections (determination of relative deficiencies). However, the information does not apply directly to libraries.
} 
we can find information that permits us to find out the number of museum libraries in departmental and branchless museums in Poland in 2017:

In the same study [Percentage distribution of space designated for different purposes in groups of branchless museums] $73.58 \%$ of institutions show that they have their own library $(\mathrm{n}=246)$, in a list including individual departments $(n=401)$ libraries are found in $48.88 \%$ of all museums including branches. (Muzea w Polsce..., 2016, Table 7, p. 27).

Thanks to the report Raport o stanie edukacji muzealnej w Polsce (Museum education in Poland. Summary of the first stage of the study) (Szelagg, 2010, p. 21) we can estimate the number of museum libraries in 2009, that is, almost 10 years ago. Of the 929 museums surveyed, half declared having a library with a reading room. It is surprising that in the report on education, the subject of museum libraries was considered only in terms of belonging to the museum infrastructure, and not for its substantive, educational, or promotional value.

As can be seen today, it is impossible to sketch any statistical picture of museum libraries in Poland. Acquiring statistical data is complicated and time-consuming, as there is no comprehensive way to collect it on a national scale. The main problem is that museum libraries are not included in GUS or NIMOZ research. In the case of library statistics, this is, unfortunately, understandable, as museum libraries are not a separate type. Only some of them have the status of scientific libraries - the Library of the National Museum in Warsaw, the Library of the Museum and Institute of Zoology of the Polish Academy of Sciences, the Princes Czartoryski Library (National Museum in Krakow), the Library of the Museum of Art in Łódź, the Library of the Museum of the Jagiellonian University, and the Library of the Natural History Museum (Wrocław University), (Obwieszczenie Ministra Kultury i Dziedzictwa Narodowego, 2016...).

It is more difficult to explain the lack of the above issues in research conducted by museum institutions, because libraries are departments in the organizational structure of home museums. Creating an additional questionnaire, including data on library infrastructure, staff, finances, collections and records collection, movement of collections, services for readers (e.g. by type - employees, researchers, learners, others), scientific, educational and promotional activities, digitisation and conservation, has allowed a closer look at the phenomenon of museum libraries. One might also be tempted to add a few questions or headings to the currently functioning sections of the survey, which were mentioned earlier, however, analysing the existing forms, it seems to be a complicated solution, hindering later search of data. A uniform questionnaire would look at the whole issue.

The fact that museum libraries are not included in NIMOZ statistics is worrying because it confirms the still visible Polish tendency to marginalize and / or underestimate the role of the library in the museum in general. 
It is a pity that the potential of museum libraries still seems underestimated, because, as Gerald Matt claims, "additional library services significantly contribute to creating the image of the museum as a comprehensive cultural institution and the dissemination of science. An open public library ${ }^{5}$ is a special element shaping the quality of disseminating culture. It is an additional place to engage the intellectual energy of the viewer and can, as happens at Centre Pompidou, become a magnet attracting the audience" (Matt, 2006, p. 149).

Reflections on the role of a museum library, its promotional potential, expectations and image among museum employees as well as the wider public and the attitude and policy of the parent institution towards the library and its employees are further topics that should be addressed, taking into account the evolution of modern museums from elite "houses of knowledge" to institutions participating in the life of local communities that describe themselves as "participatory" (Simon, 2015) ${ }^{6}$. Addressing these issues will allow a more complete definition of the phenomenon of the museum library and its functions, and will allow open reflection on possible developmental directions in the future.

\section{DEFINITION}

In the article Ksiegozbiory muzealne w Sochaczewie, Rybnie, Skierniewicach, Wyszogrodzie (Museum collections in Sochaczew, Rybno, Skierniewice and Wyszogród), Sebastian Tempczyk presents one of the few, if not the only, definition of a museum library existing in Polish literature, which is "each separate organizational unit of the museum, whose main task is to collect, develop and share the collected book museum" (Tempczyk, 2014, p. 1). This definition was probably influenced by the tendency to classify museum libraries as professional libraries according to the division used in the Act on Libraries, according to which a professional library "should be considered as a unit supporting the implementation of the tasks of workplaces and serving the needs of employees' professional development" (Ustawa, 1997).

By comparison, fourteen years earlier American author Esther Green Bierbaum gave the following definition: “...museum libraries are an integral entity within museums supporting and serving the parent institution according to the policies and standards agreed upon by both library and museum administrations" (Bierbaum, 2000, p. 1). This is still not (as the

\footnotetext{
5 „Public”, which means making the collections available outside.

${ }^{6}$ Referring to Nina Simon's concept, the participatory museum is a plane on which mutual relations are created and new content is created. Visitors' thoughts are just as important as exhibition creators and educators. The participatory museum exchanges ideas and experiences from which both sides draw. This active participation of a cultural institution will allow it to play an integrating role in the life of the local community.
} 
author herself states) a complete definition. However, as museum libraries are becoming more and more open to the external user and to scientific or educational activities related to the profile of the home museum, it seems more timely than its more recent Polish counterpart. The definition emphasizes the relationship between the library and the museum in which the library operates as well as putting the library in the position of a partner which through its activities actively participates in the life of its parent organization, as well as not limiting its activity to collecting and lending books only.

Of course, the question immediately arises as to whether this is really the case. Do Polish museum libraries enter into such partner relationships? How do the employees see the position of the museum library, and how do their superiors see it? The library-museum relationship deserves a separate study, as it is an extensive and multi-threaded topic.

Let us suggest a fragment of Marta Lange's article Wrocławskie biblioteki muzealne (Wroclaw Museum Libraries), in which the author describes the relationship between the museum library and the home museum. She senses the need for cooperation and draws attention to the benefits that may flow from this not only for libra-ries, but also for museums: "Museum libraries contain a specific collection closely related to the profile of museum collections. Both institutions supplement, complement and penetrate each other. They can function only in relation to each other. The rank of the museum is often indicated by the richness of the collection, including a valuable and unique book collection. Often, however, a museum library is perceived only as a supplement to the collection of a given museum, and often becomes overlooked and neglected". (Lange, 2014, p. 30).

When defining a museum library, in addition to establishing the relationship between museum library and museum, one should also specify what type of library it is. Here the question arises whether it is subject to such categorisation at all. Divisions seem obvious up to some point. No museum library is an independent being from the formal and legal point of view. Most also make collections available to users only in the reading room. Museum libraries can be financed by the state (e.g. national), local government (e.g. city museums), non-governmental organizations or even private individuals. There are museum library collections on international subjects (e.g. contemporary art museums, World War II Museum, Museum of Emigration), national (national museums, Literature Museum, Independence Museum), regional (district museums), urban or local (museums of battles, local personalities).

Nevertheless, it is most difficult to classify museum libraries according to the nature and needs of their users, because this categorisation, a phenomenon of the 21st century, is something the museum library completely escapes. 


\section{SCIENTIFIC, PROFESSIONAL OR “SPECIALIST"?}

The Act on Libraries (Ustawa z dnia 27 czerwca 1997 r. o bibliotekach) divides Polish libraries into public, scientific, school and pedagogical, professional and company libraries. Only six museum libraries have the formal status of a research library. Others, though the name often has the adjective "scientific", do not have such a status. Their collections and activities have a "scientific character". By signaling their profile in this way, they also want to interest a specific group of users.

Most museum libraries call themselves professional. Piotr Milc, author of the article Biblioteki specjalistyczne - typologia i prawne podstawy dziatania (Specialist libraries - typology and legal basis of operation) (Milc, 2018, p. 13), who places them between departmental, industry and workplace libraries, agrees with this statement.

Indeed, originally " $t]$ he museum library was seen as a tool to provide support to the museum staff alone and museum-libraries were not regarded as for the public at all and in many instances they retain to this day the character of a private library" (Wateren, 1999, p. 192). It is true that the basic tasks of museum libraries were and are still collecting, developing and making available to employees library materials pertaining to the profile of the museum and its collections, as well as documenting the substantive activities of the museum and its employees. However, the limitation of the function of museum libraries only to service employees of the parent institution was relevant about ten years ago. Today it should be considered a significant narrowing of their current operations.

Museum libraries in the second decade of the 21st century, although sometimes still technologically delayed or run by people who are not always librarians by profession, go beyond the definition of a professional library focused on serving museum staff. They make the collections available to outside users in reading rooms, thus opening them to a wider audience, usually from academic and school environments. It should also be taken into account that the organisational regulations of museums and their superiors often oblige librarians to popularise the collection and promotion of a library/museum in the environment through the organisation of author meetings, literary evenings and scientific activities such as the organisation of lectures, participation in scientific, or even educational conferences such as conducting library or museum lessons etc. (Regulamin... Muzeum Warszawy, 2018; Regulamin... Muzeum Narodowego Ziemi Przemyskiej, 2017; Regulamin... Muzeum Archeologiczno-Historycznego, 2017).

A museum library operating in this way ceases to be just a professional library within the meaning of the definition of the Act on Libraries. It is not only intended to educate and expand the knowledge of its users. It enters the field of scientific libraries (conducting its own research and docu- 
menting research activities of employees of the unit in which it operates) and/or even public libraries (organizing meetings, workshops, library and museum lessons, actively participating in the Night of Museums and Libraries). Therefore, one should ask another question: can this eclectic creation, which is a museum library, fit into the framework of functioning classifications?

The contemporary museum library, reconciling the realms of library as well as museum, scientific, educational and dissemination functions, tries to flexibly combine traditional activities with new elements, allowing it to meet the needs of subsequent types of users. In this way, it creates a kind of hybridity of services offered.

It seems, therefore, that the typology used in the Act on Libraries according to the nature and needs of users is not sufficient, because it is not so much about the type of reader in this case as it is about the information to which the museum library provides access. After all, museum employees, scientists, and students, as well as students and enthusiasts of a given topic, can use the professional library. The common denominator seems to be rather the field which is of interest to the abovementioned readers at various levels of detail. This is where UNESCO's typology of November 13, 1972 - Recommendation concerning the international standardization of library statistics (Recommendation, 1970) - can help, in which, in addition to national libraries, universities, major universal, school and public libraries, specialty libraries (also translated as "special"7) were also highlighted, and where "the greater part of collections represents a specific field of science or subject [...]", serving "anyone who needs them" (Morsztynkiewiczowa 1972, p. 202). They can also be libraries "whose collections and activities are primarily intended to meet the information needs of their main users, even when they meet the information needs of specialists outside the group of those entitled services" (Morsztynkiewiczowa 1972, p. 202). The specialized libraries of UNESCO include libraries maintained by associations, government ser-vices, parliaments, research institutes (non-university), professional associations, museums, enterprises and chambers of commerce.

Although the definition contained in the recommendations was created more than forty years ago, it seems to be better suited to the phenomenon of the modern museum library, because it refers to the profile of the collection and takes into account the specific user, while not ignoring the public aspect of its activity. Of course, one should ask the further question whether it is necessary to isolate another category of libraries. Maybe it

\footnotetext{
${ }^{7}$ For the purposes of this article, the translation of "specialized libraries" will be used so as not to be confused with the term "special libraries", i.e. for special groups of users (libraries for the blind, in medical entities, prisons, etc.).
} 
would be enough to expand the current definition of a professional library?

We are entering the field of semantics here, because "professional" refers to a profession, something devoted to some profession, or associated with it (Skorupka, ed., 1968, p. 169), while the word "specialist" is associated with a specialty, related to specialization, where specialization is acquiring knowledge, skills, proficiency in some field (Skorupka, ed., 1968, p. 763). These are synonyms, however, there is a small but fundamental difference that can be seen very clearly in the example of museum libraries, whose collections primarily reflect the profile of the home museum (e.g. regional museums collect regional, urban literature on the city in which they operate, etc.). These collections are usually the most important part of the collection, and the most valuable copies may even have the status of museum exhibits. Exhibits for exhibitions will be chosen from them. The remaining "working" collection consists of items needed by technical staff for their ongoing scientific activities (including in the field of art history, museum studies, law, conservation, cultural heritage, etc.). With a limited budget, museum libraries give priority to literature that supplements their basic domain collection, which often differs from the collections of regional public libraries. Forming collections and creating a library collection in a museum that serves as a witness to an era and a potential exhibit is another interesting topic worth exploring.

\section{SUMMARY}

For the moment, the author will not attempt to create a general definition of a museum library on Polish soil, because before that one must first think about the relations connecting the library with its originating institution and decide in which direction the modern museum library should go.

Museums, their philosophy of operation and the way they cooperate with users influence the image of today's museum library, which goes beyond the framework of its "professionalism", looking for new readers and opening up to the local community. At the same time, while looking for confirmation of its substantive status and rightful place in the organizational structure of the parent organization, the museum library uses research tools and activities.

In this, the relationship of museum library to museum is not surprising. Going back to the beginnings of museums, it is hard not to notice that the ancient sense of the word "musaeum" is "house of the muses", i.e. "a place of inspiration and a repository of the effects of creative inspiration" (Folga-Januszewska, 2015, pp. 15-16). You can look at the library in 
exactly the same way - not as a collection of books (in Greek biblion means a book), but a place where knowledge and inspiration for further creative activity takes place. It should also be remembered that the first libraries were museum libraries in a sense, i.e. those established at the museums in Athens and Alexandria. Let the conclusion be the encouragement of researchers to, like the author of this article, "return to their roots", because the subject of museum libraries is still a blank spot on the map of Polish library science.

When considering the issue of museum libraries on a theoretical basis, one should not lose sight of formal and organizational issues (including their place in the library system in Poland), as they largely determine the daily functioning of museum libraries and the way they are managed.

\section{BIBLIOGRAPHY}

Adamek, Anna (2000). Biblioteka Muzealna - z doświadczeń Muzeum Narodowego Nauki i Techniki w Ottawie. EBIB. Elektroniczny Biuletyn Informacyjny Bibliotekarzy [online]. No. 3; [accessed on: 27.05.2019]. Available on WWW: <http://www.ebib.pl/biuletynebib/11/a.php?adamek>

Benedetti, Joan M., ed. (2007). Art Museum Libraries and Librarianship, Lanham: The Scarecrow Press, Art. Libraries Society of North America.

Bierbaum, Esther Green (2000). Museum Librarianship, Jefferson: McFarland \& Company Publishers.

Długosz, Justyna (2018). Biblioteka Muzeum Śląskiego w Katowicach - współczesna biblioteka muzealna w nowoczesnej instytucji kultury. In: Multibibliotekarstwo: praca zbiorowa. Ed. M. Wojciechowska. Warszawa: Wydaw. SBP, pp. 197-207.

Folga-Januszewska, Dorota (2009). Muzea w Polsce 1989-2008. Muzealnictwo, no. 50, pp. 24-25.

Folga-Januszewska, Dorota (2015). Muzeum: fenomeny i problemy. Kraków: Universitas, pp. 15-16.

Jeznak, Hanna (2009). Biblioteka Muzeum Sportu i Turystyki: 1959-2009. Warszawa: Muzeum Sportu i Turystyki.

Kurzyńska, Marta (2017). Biblioteka Muzeum Narodowego w Szczecinie - przemiany i perspektywy rozwoju. In: Stan i perspektywy rozwoju bibliotek zachodniopomorskich: 10 lat później: materiały z konferencji w Bibliotece Głównej Uniwersytetu Szczecińskiego, 2 grudnia 2014 roku. Szczecin: Książnica Pomorska im. Stanisława Staszica, pp. 104-114.

Lange, Marta (2014). Wrocławskie biblioteki muzealne. Bibliotekarz no. 3.

Makała, Rafał (2009). Muzeum prowincjonalne? Geneza, historia i koncepcja rozwoju Muzeum Narodowego w Szczecinie. Muzealnictwo, no. 50, p. 156.

Matt, Gerald (2006). Muzeum jako przedsiębiorstwo: łatwo i przystępnie o zarzadzaniu instytucja kultury. Warszawa: Fundacja Aletheia.

Mazik, Magdalena (2013). Gościnność przestrzeni. Rozmowa z Magdaleną Mazik, kierowniczką biblioteki MOCAK-u [online]. Szum, 2013 [accessed on: 24.04.2019]. Available on WWW: <https://magazynszum.pl/goscinnosc-przestrzeni-rozmowa-z-magdalenamazik-kierowniczka-biblioteki-mocak-u/>. 
Milc, Piotr (2018). Biblioteki specjalistyczne - typologia i prawne podstawy działania. Biblioteka i Edukacja, no. 14.

Morsztynkiewiczowa, Irena (1972). Zagadnienia statystyki bibliotecznej na forum międzynarodowym. Przeglad Biblioteczny, no. 2.

Muzea w Polsce. Raport na podstawie danych z projektu "Statystyka muzeów" 2013-2015 (2016). Warszawa: Narodowy Instytut Muzealnictwa i Ochrony Zbiorów. [accessed on: 27.05. 2019]. Available on WWW: <https://www.nck.pl/badania/raporty/raport-muzea-wpolsce-2013-2015->.

Muzea w Polsce w 2017 roku [online]. Warszawa: Narodowy Instytut Muzealnictwa i Ochrony Zbiorów [accessed on: 27.05.2019]. Available on WWW: <https://www.nimoz.pl/ files/publications/55/Statystyka_muzeow_2017_online.pdf $>$.

Muzeum OdNowa. Modernizacja kamienic Muzeum Warszawy 2015-2018 (2018). Warszawa: Muzeum Warszawy.

Niechcaj-Nowicka, Elżbieta (2014). Biblioteka Muzeum Poczty i Telekomunikacji we Wrocławiu. Ksiażka i Czytelnik, no. 3, pp. 14-16.

Obwieszczenie Ministra Kultury i Dziedzictwa Narodowego z dnia 21 stycznia 2016 r. w sprawie ogłoszenia jednolitego tekstu rozporządzenia Ministra Kultury i Dziedzictwa Narodowego w sprawie sposobu i trybu zaliczania bibliotek do niektórych bibliotek naukowych oraz ustalenia ich wykazu [online], [accessed on: 23.04.2019]. Available on WWW: <http://prawo.sejm. gov.pl/isap.nsf/download.xsp/WDU20160000137/O/D20160137.pdf>.

Recommendation concerning the intemational standardization of library statistics, 13 November 1970 (1970). Paris: The General Conference of the United Nations Educational, Scientific and Cultural Organization. [accessed on: 26.04.2019]. Available on WWW: $<$ http://portal.unesco.org/en/ev.php-URL_ID=13086\&URL_DO=DO_TOPIC\&URL_ SECTION=201.html>.

Regulamin Organizacyjny Muzeum Warszawy z dn. 15.11.2018 r. (2018) [online]. Warszawa: Muzeum Warszawy. [accessed on: 22.05.2019]. Available on WWW: <https://muzeumwarszawy.pl/wp-content/uploads/2018/11/Zarz\%C4\%85dzenie-nr-44_2018-w-spr.wprowadzenia-Regulaminu-Organizacyjnego-MW.pdf $>$.

Regulamin Organizacyjny Muzeum Narodowego Ziemi Przemyskiej w Przemyślu z dn. 7.04. 2017 r. (2017). [online]. Przemyśl: Muzeum Narodowe Ziemi Przemyskiej w Przemyślu. [accessed on: 22.05.2019]. Available on WWW: <https://mnzp.pl/bip/pl/zawartoscregulamin-organizacyjny>.

Regulamin Organizacyjny Muzeum Archeologiczno-Historycznego w Stargardzie (2017). [online]. Stargard: Muzeum Archeologiczno-Historyczne w Stargardzie. [accessed on: 22.05.2019]. Available on WWW: <http://muzeum-stargard.pl/pl/o-muzeum/bip/regulamin-organizacyjny-muzeum/>.

Rewitalizacja infrastruktury Muzeum Sztuki w Łodzi - Gdańska 43 (2016). W: Lista łódzkich projektów sektora kultury, które otrzymały dofinansowanie w dniu 19 września 2016 r. [online], [accessed on: 23.04.2019]. Available on WWW: <https://www.funduszeeuropejskie. gov.pl/media/26512/20160920_informacja_o_projektach.pdf>

Simon, Nina (2015). Muzeum partycypacyjne. In: Laboratorium Muzeum. Społeczność. Editors: A. Banaś, A. Janus. Warszawa: Muzeum Warszawy, pp. 22-37.

Skorupka, Stanisław, ed. (1968). Mały Słownik Języka Polskiego. Warszawa: PWN.

Sobczyk, Sławomir (2012). Biblioteki muzeów sztuki na przykładzie biblioteki Arxiu CCCB w Barcelonie i Biblioteka de Arte Muzeum Gulbenkiana w Lizbonie. Biblioteka i Edukacja, No. 2, pp. 1-13. 
Siuciak, Aleksandra (2013). Biblioteka Muzeum Zamkowego w Malborku. Forum Bibliotek medycznych, no. 1, pp. 238-265.

Stan bibliotek $w$ Polsce... Wybrane dane $i$ wskaźniki, oprac. Biblioteka Narodowa [online]. Warszawa: BN [accessed on: 27.05.2019]. Available on WWW: <https://www.bn.org.pl/ projekty/raporty-bn/stan-bibliotek-w-polsce>.

Statystyka Muzeów (2017). Ed. Narodowy Instytut Muzealnictwa i Ochrony Zabytków [accessed on: 26.05.2019]. Available on WWW: <https://statystykamuzeow.nimoz.pl/>.

Szeląg, Marcin (2010). Raport o stanie edukacji muzealnej w Polsce. Podsumowanie I etapu badań (online). Poznań: Muzeum Narodowe w Poznaniu, Forum Edukatorów Muzealnych. [accessed on: 23.04.2019]. Available on WWW: <http://webcache.googleusercontent. com/search?q=cache:midfMF_YDvoJ:www.wilanowpalac.pl/download.php/15736/ raport_o_stanie_edukacji_muzealnej_w_polsce_podsumowanie_i_etapu_badan_ $\mathrm{pdf}+\& \mathrm{~cd}=8 \& \mathrm{hl}=\mathrm{pl} \& \mathrm{ct}=\mathrm{clnk} \& \mathrm{gl}=\mathrm{pl}>$.

Tempczyk, Sebastian (2014). Księgozbiory muzealne w Sochaczewie, Rybnie, Skierniewicach i Wyszogrodzie. EBIB elektroniczny Biuletyn Informacyjny Bibliotekarzy [online], no 7; [accessed on: 23.04.2019]. Available on WWW: <http://open.ebib.pl/ojs/index.php/ ebib/article/view/280/453>.

Ustawa z dnia 27 czerwca 1997 r. o bibliotekach (1997). Dz. U. Nr 85, poz. 539. [accessed on: 26.05.2019]. Available on WWW: <http://prawo.sejm.gov.pl/isap.nsf/download.xsp/ WDU20120000642/T/D20120642L.pdf>.

Wateren, Jan van der (1999). The importance of museum libraries. International Journal of Special Libraries, vol. 4, p. 191.

Zintegrowany System Informacji o Nauce i Szkolnictwie Wyższym. Ministerstwo Nauki i Szkolnictwa Wyższego. [accessed on: 24.04.2019]. Available on WWW:_https://polon. nauka.gov.pl/opi/aa/biblioteki>.

Žák-Caplot, Katarzyna (2018). Biblioteka muzealna OdNowa, czyli między drugim a trzecim miejscem. In: Nowe zmiany a kondycja bibliotek. Wrocław: Korporacja Bibliotekarzy Wrocławskich, Dolnośląska Biblioteka Pedagogiczna, pp. 31-43.

Žák-Caplot, Katarzyna (2018). Rozwój kolekcji Biblioteki Muzeum Warszawy do roku 1986. Almanach Warszawy, vol. 11, pp. 345-356. 